\title{
Trichosporon japonicum sp. nov. isolated from the air
}

\author{
Takashi Sugita and Takashi Nakase
}

\begin{abstract}
Author for correspondence: Takashi Sugita. Tel: +81484621111 ext. 5153. Fax: +81484624619 e-mail: sugita $a$ ulmus.riken.go.jp
\end{abstract}

\author{
Japan Collection of \\ Microorganisms, The \\ Institute of Physical and \\ Chemical Research (RIKEN), \\ 2-1 Hirosawa, Wako, \\ Saitama 350-0198, Japan
}

\begin{abstract}
A yeast strain isolated from the air in Japan was found to represent a new species, and was named Trichosporon japonicum. This species produced arthroconidia and appressoria. T. japonicum formed a cluster with the appressorium-forming species Trichosporon inkin and Trichosporon ovoides in a phylogenetic tree constructed using small-subunit rDNA sequences. However, they had low relatedness to each other in DNA-DNA hybridization experiments. $T$. japonicum is distinguished from both $T$. inkin and $T$. ovoides by its ability to assimilate inulin, and its inability to assimilate L-rhamnose. JCM $8357^{\top}$ is the type strain of the species.
\end{abstract}

Keywords: Trichosporon japonicum sp. nov., yeast

\section{INTRODUCTION}

Basidiomycetous anamorphic yeasts of the genus Trichosporon Behrend are characterized by the production of arthroconidia and the presence of xylose in the cells. In 1992, Guého et al. proposed the new taxonomy of the genus Trichosporon based on the partial sequences of large-subunit rRNA and DNA relatedness. Presently, 17 species and five varieties are recognized within the genus (Guého et al., 1992; Sugita et al., 1994, 1995). Of these, 13 species possess Q-9 as the major ubiquinone, while the other four possess Q10. The strain JCM $8357^{\mathrm{T}}$ used in this study was isolated from the air in 1971. This strain has been maintained in the Central Research Laboratories, Ajinomoto Co. Inc., as Prototheca species. However, the isolate seemed to be closely related to Trichosporon inkin and Trichosporon ovoides, because it produced arthroconidia and appressoria. A comparative taxonomic study among these three yeasts revealed that the strain JCM $8357^{\mathrm{T}}$ represented a new species. Trichosporon japonicum Sugita et Nakase sp. nov. is proposed for this isolate.

\section{METHODS}

Strains examined. The strain $\mathrm{JCM} 8357^{\mathrm{T}}$ reported in this paper was supplied from Central Research Laboratories, Ajinomoto Co. Inc., Kawasaki, Kanagawa Pref., Japan, as JCM $8357^{\top}$ is $A B 001749$.
Prototheca sp. AJ 14673. It was isolated in 1971 as an air contaminant in a microbiological laboratory.

Morphological, biochemical and physiological characteristics. Most of the morphological, biochemical and physiological characteristics were examined using the methods described by van der Walt (1984). Assimilation of nitrogen compounds was investigated according to the methods of Nakase \& Suzuki (1986). Vitamin requirements were examined using the methods of Komagata \& Nakase (1967). The maximum growth temperature was determined in YM broth (Difco) using metal heating blocks.

Examination of chemotaxonomic characteristics. Extraction, purification and identification of ubiquinones were carried out according to the methods of Nakase \& Suzuki (1988). The presence of xylose in the cells was determined using methods described by Suzuki \& Nakase (1988). Isolation and purification of DNA followed the methods of Nakase \& Suzuki (1986). The DNA base composition (mol \% G+C) was determined by using HPLC after digesting the DNA with nuclease Pl (Yamasa Shouyu) and alkaline phosphatase (Sigma) as described by Nakase et al. (1989). DNA-DNA hybridization experiments were performed using the membrane-filter method of Nakase \& Suzuki (1985).

Sequencing of small-subunit rDNA (SSU rDNA). The SSU rRNA coding region was amplified by the PCR as described in Suh \& Nakase (1995). The PCR product was sequenced by using the Sequi Therm Long-Read Cycle Sequencing Kit (Epicentre Technologies) with the primers described in Suh et al. (1996). Analyses of DNA sequence reactions were performed on an ALFexpress DNA sequencer (Pharmacia Biotech).

Phylogenetic analysis. The sequences were aligned using the 
CLUSTAL w computer program (Thompson et al., 1994). For phylogenetic analysis, SSU rDNA sequences of related basidiomycetes were obtained from the EMBL, GenBank and DDBJ nucleotide sequence databases. The urediniomycetous yeasts Rhodosporidium toruloides (D12806) and Sporidiobolus johnsonii (L22261) were used as outgroups. Kimura's two-parameter distances (Kimura, 1980) were used for the neighbour-joining analysis (Saito \& Nei, 1987). Sites where gaps existed in any of the sequences were excluded from the analysis. Bootstrap analysis was performed using 1000 random replications (Felsenstein, 1985).

\section{RESULTS AND DISCUSSION}

\section{Latin diagnosis of Trichosporon japonicum Sugita et Nakase sp. nov.}

In liquido ' $Y M$ ', post dies 5 ad $25^{\circ} \mathrm{C}$, cellulae ovoideae, ellipsoideae, elongatae, $(4 \cdot 5-9 \cdot 6) \times(5 \cdot 8-9 \cdot 7) \mu \mathrm{m}$, singulae aut binae. Sedimentum formatur. Post unum mensem ad $25^{\circ} \mathrm{C}$, anulus et sedimentum formantur. In agaro ' $Y M$ ', post unum mensem ad $25^{\circ} \mathrm{C}$, cultura eburnea, margine erosa. Appressorium, arthroconidium aut mycelium formatur. Fermentatio nulla. Glucosum, galactosum, L-sorbosum, saccharosum, maltosum, cellobiosum, trehalosum, lactosum, melezitosum, inulinum (exiguum), amylum solubile, D-xylosum, L-arabinosum, D-arabinosum (exiguum), D-ribosum, ethanolum (exiguum), glycerolum (exiguum), erythritolum, ribitolum (exiguum), galactitolum, D-mannitolum (exiguum), Dglucitolum, methyl $\alpha$-D-glucosidum, salicinum, glucono$\delta$-lactonum (exiguum), acidum 2-ketogluconicum, acidum D-glucuronicum (exiguum), acidum D-galacturonicum (exiguum), acidum DL-lacticum, acidum succinicum, acidum citricum (exiguum), et $\mathrm{N}$-acetylglucosaminum assimilantur at non melibiosum, raffinosum, L-rhamnosum, acidum 5-ketogluconicum, inositolum, nhexadecanum, D-glucosaminum, methanolum nec $D$ saccharicum. Ammonium sulfatum, ethylaminum, $L^{-}$ lysinum et cadaverinum assimilantur at non kalium nitricum nec natrium nitrosum. Maxima temperatura crescentiae: $39-40{ }^{\circ} \mathrm{C}$. Ad crescentiam biotimum necessarium est. Diazonium caeruleum B positivum. Proportio molaris guanini + cytosini in acido deoxyribonucleico: $59.8 \mathrm{~mol} \%$ (per HPLC). Ubiquinonum majus: Q-9.Xylosum in cellulis presens. Holotypus: isolatus ex ventilare, $\mathrm{JCM} 8357^{\mathrm{T}}$ conservatur in collectionibus. culturarum quas 'Japan Collection of Microorganisms', Wako, Saitama sustentat.

\section{Description of Trichosporon japonicum Sugita et Nakase sp. nov.}

Trichosporon japonicum (ja.po'ni.cum. M.L. masc. adj. japonicum pertaining to Japan, where the organism was isolated).

Growth in YM broth: After $5 \mathrm{~d}$ at $25^{\circ} \mathrm{C}$, cells are ovoidal, ellipsoidal, elongate, $(4 \cdot 5-9 \cdot 6) \times(5 \cdot 8-9 \cdot 7) \mu \mathrm{m}$, single or in pairs (Fig. 1a). A sediment is formed. After 1 month at $25^{\circ} \mathrm{C}$, a ring and a sediment are present. Growth on YM agar: After 1 month at $25^{\circ} \mathrm{C}$, the
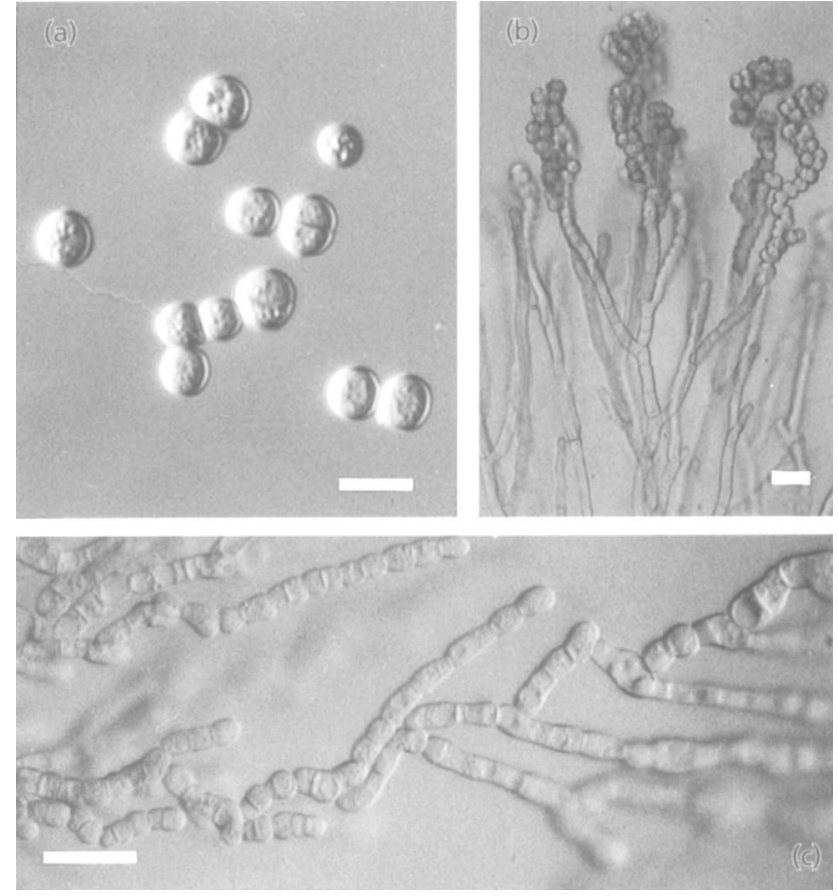

Fig. 1. Morphology of Trichosporon japonicum sp. nov. after growth for $5 \mathrm{~d}$ at $25^{\circ} \mathrm{C}$. (a) Vegetative cells grown in YM broth. (b) Appressoria produced on corn meal agar. (c) Arthroconidia produced on corn meal agar. Bars, $10 \mu \mathrm{m}$.

streak culture is ivory and has an erose margin. Dalmau plate culture on corn meal agar: appressoria, arthroconidia and mycelia are produced (Fig. Ib and 1c). Fermentation: absent. Assimilation of carbon compounds: glucose, + ; ribitol, + (weak); galactose, + ; galactitol, +; L-sorbose, +; D-mannitol, + (weak); sucrose, + ; D-glucitol, + ; maltose, + ; methyl $\alpha$-D-glucoside, + ; cellobiose, + ; salicin, + : trehalose, + ; glucono- $\delta$-lactone, + (weak); lactose, + ; 2-ketogluconic acid, +; melibiose, -; 5-ketogluconic acid, -; raffinose, - ; D-glucuronic acid, $+($ weak $)$; melezitose, +; D-galacturonic acid, $+($ weak $)$; inulin, + (weak); DL-lactic acid, + ; soluble starch, +; succinic acid, +; D-xylose, +; citric acid, $+($ weak $)$; L-arabinose, + ; inositol, - ; D-arabinose, + (weak); n-hexadecane, - ; D-ribose, +; D-glucosamine, - ; L-rhamnose, $-; \mathrm{N}$-acetylglucosamine, + ; ethanol, +(weak); methanol, - ; glycerol, + (weak); D-saccharic acid, - ; erythritol, + . Assimilation of nitrogen compounds: ammonium sulfate, + ; ethylamine hydrochloride, + ; potassium nitrate, - ; $L$ lysine hydrochloride, + ; sodium nitrite, - ; cadaverine dihydrochloride, + . Maximum growth temperature: $39-40{ }^{\circ} \mathrm{C}$. Vitamins required: biotin. Production of starch-like substances: negative. Growth on $50 \%$ $(w / w)$ glucose-yeast extract agar: negative. Urease: positive. Liquefaction of gelatin: negative. Hydrolysis of fat: negative. Diazonium blue $\mathrm{B}$ reaction: positive. $\mathrm{G}+\mathrm{C}$ content of nuclear DNA: $59 \cdot 8 \mathrm{~mol} \%$ (by 


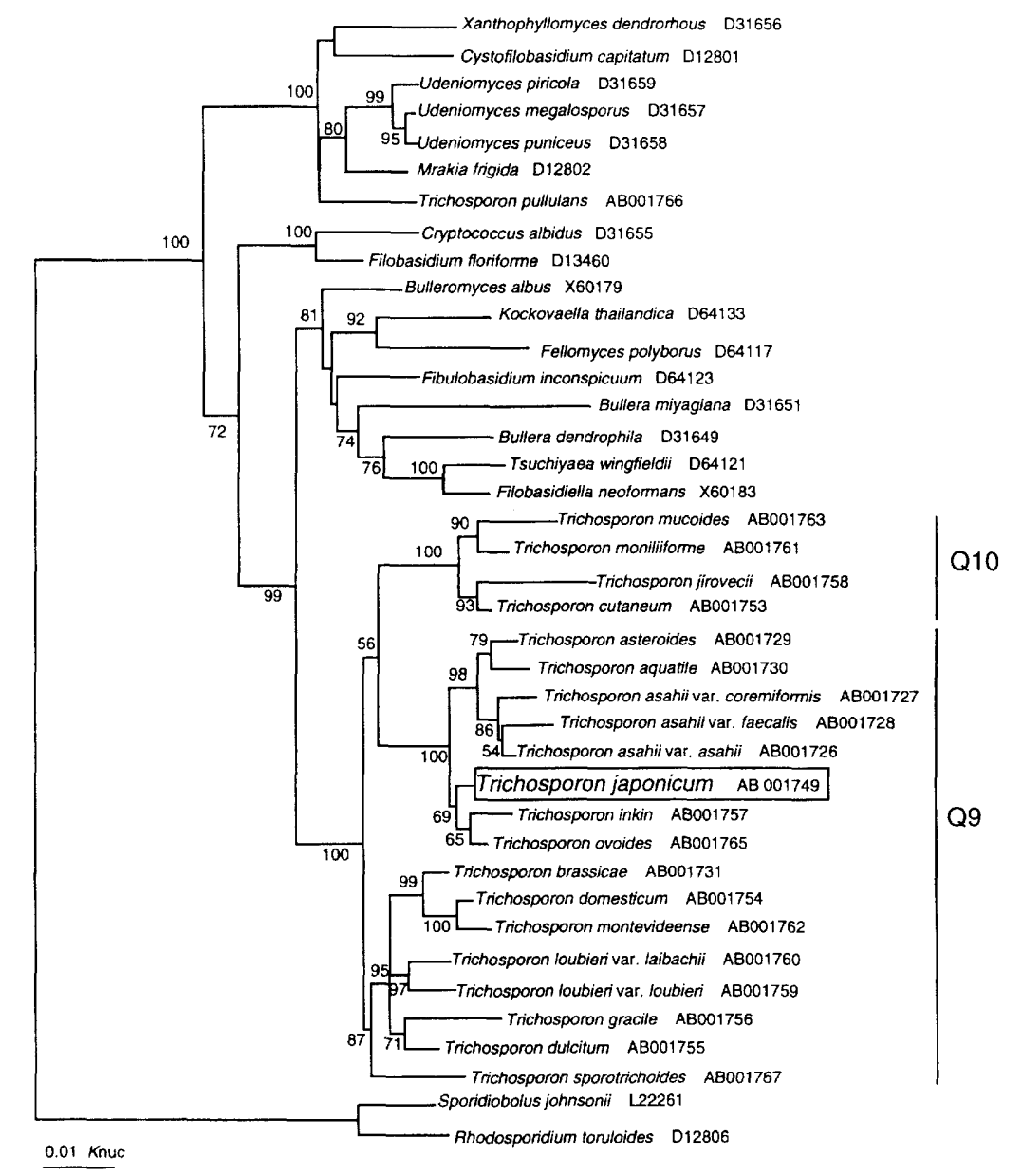

Fig. 2. Neighbour-joining tree resulting from analysis of SSU rDNA sequences of Trichosporon japonicum sp. nov. and related taxa. The numerals represent the confidence level from 1000 replicate bootstrap sampling (the frequency less than $50 \%$ was not indicated).

Table 1. DNA relatedness among Trichosporon japonicum and phylogenetically closely related species

\begin{tabular}{|c|c|c|c|c|c|}
\hline \multirow[t]{2}{*}{ Species } & \multirow[t]{2}{*}{ Strain } & \multirow{2}{*}{$\begin{array}{c}G+C \text { content } \\
(\mathrm{mol} \%)\end{array}$} & \multicolumn{3}{|c|}{ Relative binding (\%) of DNA with: } \\
\hline & & & JCM $8357^{\mathrm{T}}$ & JCM 9940' & JCM $9195^{\top}$ \\
\hline Trichospuron japonicum & JCM $8357^{\prime \prime}$ & $59 \cdot 8$ & 100 & 29 & 29 \\
\hline Trichosporon ovoides & $\mathrm{JCM} 9940^{\mathrm{T}}$ & $58 \cdot 5^{*}, 60 \cdot 1 \dagger$ & 24 & 100 & 23 \\
\hline Trichosporon inkin & JCM $9195^{\top}$ & $59 \cdot 5^{*}$ & 27 & 27 & 100 \\
\hline
\end{tabular}

* Guého e' al. (1992).

† Sugita el al. (1994).

HPLC). Major ubiquinone: Q-9. Xylose in the cells: present. Type strain: JCM $8357^{\mathrm{T}}$, isolated by $\mathrm{M}$. Hoshino from the air in 1971, Kawasaki, Kanagawa Pref., Japan. This strain has been deposited in the Japan Collection of Microorganisms, Wako, Saitama.

Morphologically, the genus Trichosporon is characterized by the production of septate mycelia and arthroconidia. A few species possess additional diagnostic morphological characters, such as the production of appressoria, macroconidia or meristematic conidiation. Strain JCM $8357^{\mathrm{T}}$ produced appressoria on a slide culture of corn meal agar. The only species in the genus Trichosporon that produce appressoria are $T$. inkin and $T$. ovoides. We have already determined the SSU rDNA sequences for all of the species in the genus Trichosporon (Sugita \& Nakase, 1997). The sequence data showed that the genus Trichosporon, with the exception of Trichosporon pullulans, was monophyletic although the members of the genus Trichosporon have two different major ubiquinones, Q-9 and Q-10. T. japonicum formed a cluster with the 
Table 2. Differential characteristics of Trichosporon japonicum and phylogenetically closely related Trichosporon species

+ , Positive; - , negative; w, weak.

\begin{tabular}{|lccc|}
\hline Species & \multicolumn{2}{c|}{ Assimilation of: } & Appressoria \\
\cline { 2 - 4 } & Inulin & L-Rhamnose & \\
\hline T. japonicum & $\mathrm{W}$ & - & + \\
T. inkin & - & - & + \\
T. ovoides & - & + & + \\
T. asahii var. asahii & - & + & - \\
T. asahii var. coremiformis & - & + & - \\
T. asahii var. faecalis & - & + & - \\
T. asteroides & - & + & - \\
T. aquatile & - & - & \\
\hline
\end{tabular}

appressorium-producing species, $T$. inkin and $T$. ovoides (Fig. 2). On the basis of this phylogenetic analysis, we also performed a DNA-DNA hybridization experiment. As shown in Table 1, the DNA of $T$. japonicum indicated low relatedness values (23$29 \%$ ) with either $T$. inkin or $T$. ovoides. This result suggests that $T$. japonicum represents a new species in the genus Trichosporon.

In practice, $T$. japonicum is distinguished from the phylogenetically closely related species Trichosporon asahii var. asahii, Trichosporon asahii var. coremiformis, Trichosporon asahii var. faecalis, Trichosporon asteroides, Trichosporon aquatile, $T$. inkin and $T$. ovoides by its ability to assimilate inulin, its inability to assimilate L-rhamnose, and the production of appressoria (Table 2).

\section{ACKNOWLEDGEMENTS}

We thank Mr Masami Hoshino and Dr Shigeru Yamanaka, Central Research Laboratories, Ajinomoto Co. Inc., Kawasaki, who gave us the strain employed in the present paper.

\section{REFERENCES}

Felsenstein, J. (1985). Confidence limits on phylogenies: an approach using the bootstrap. Evolution 39, 783-791.

Guého, E., Smith, M. Th., de Hoog, G. S., Billon-Grand, G., Christen, R. \& Batenburg-van der Vegte, W. H. (1992). Contributions to a revision of the genus Trichosporon. Antonie Leeuwenhoek 61, 289-316.

Kimura, M. (1980). A simple method for estimation evolutionary rate of base substitutions through comparative studies of nucleotide sequences. $J$ Mol Evol 16, 111-120.

Komagata, K. \& Nakase, T. (1967). Microbiological studies on frozen foods. V. General properties of yeasts isolated from frozen food. Shokuhin Eiseigaku Zasshi 8, 53-57 (in Japanese).

Nakase, T., Itoh, M. \& Sugiyama, J. (1989). Bensingtonia ingoldii sp. nov., a ballistospore-forming yeast isolated from Knightia excelsa collected in New Zealand. J Gen Appl Microbiol 35. 53-58.

Nakase, T. \& Suzuki, M. (1985). Taxonomic studies on Deharyomyces hansenii (Zopf) Lodder et Kreger-van Rij and related species. I. Chemotaxonomic investigations. J Gen Appl Microbiol 31, 49-69.

Nakase, T. \& Suzuki, M. (1986). Bullera megalospora, a new species of yeast forming large ballistospores isolated from dead leaves of Oryza sativa, Miscanthus sinensis, and Sasa sp. in Japan. J Gen Appl Microbiol 32, 225-240.

Nakase, T. \& Suzuki, M. (1988). Sporobolomyces yuccicola, a new species of ballistosporous yeast equipped with ubiquinone- 9 . Antonie Leeuwenhoek 54, 45-55.

Saito, N. \& Nei, M. (1987). The neighbor-joining method: a new method for reconstructing phylogenetic trees. $\mathrm{Mol} \mathrm{Biol} \mathrm{Evol} 4$. 406-425.

Sugita, T. \& Nakase, T. (1997). Molecular phylogenetic study of the basidiomycetous anamorphic yeast genus Trichosporon and related taxa based on small subunit ribosomal DNA sequences. Mycoscience 39, 1-10.

Sugita, T., Nishikawa, A. \& Shinoda, T. (1994). Reclassification of Trichosporon cutaneum by DNA relatedness by using the spectrophotometric method and the chemiluminometric method. J Gen Appl Microbiol 40, 397-408.

Sugita, T., Nishikawa, A., Shinoda, T., Yoshida, K. \& Ando, M. (1995). A new species, Trichosporon domesticum, isolated from the house of a summer-type hypersensitivity pneumonitis patient in Japan. J Gen Appl Microbiol 41, 429-436.

Suh, S.-O. \& Nakase, T. (1995). Phylogenetic analysis of the ballistosporous anamorphic genera Udeniomyces and Bullera, and related basidiomycetous yeasts based on $18 \mathrm{~S}$ rDNA sequence. Microbiology 141, 901-906.

Suh, S. O., Takashima, M., Hamamoto, M. \& Nakase, T. (1996). Molecular phylogeny of the ballistoconidium-forming anamorphic yeast genus Bullera and related taxa based on small subunit ribosomal DNA sequences. J Gen Appl Microbiol 42. 501-509.

Suzuki, M. \& Nakase, T. (1988). The distribution of xylose in the cells of ballistosporous yeasts - application of high performance liquid chromatography without derivatization to the analysis of xylose in whole cell hydrolysates. J Gen Appl Microbiol 34, 95-103. 
Thompson, J. D., Higgins, D. G. \& Gibson, T. J. (1994). CLUSTAL $\mathrm{W}$ : improving the sensitivity of progressive multiple sequence alignment through sequence weighting, position-specific gap penalties and weight matrix choice. Nucleic Acids Res 22, $4673-4680$.
Van der Walt, J. P. \& Yarrow, D. (1984). Methods for the isolation, maintenance, classification and identification of yeasts. In The Yeasts: a Taxonomic Study, 3rd edn, pp. 45-105. Edited by N. J. W. Kreger-van Rij. Amsterdam: Elsevier. 
